\title{
SEVERE LIVER DYSFUNCTION IN SYSTEMIC LUPUS ERYTHEMATOSUS: CMV INFECTION AND/OR DISEASE ACTIVITY: CASE REPORT
}

Alisson Regis de Santana ${ }^{1, \star}$, Anna Paula Mota Duque Sousa ${ }^{1}$, Viviane Leal Novais ${ }^{1}$, Maria de Lourdes Castro de Oliveira ${ }^{1}$, Renata Borges de

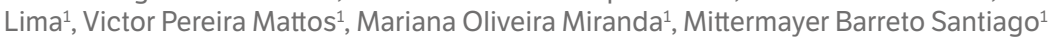

1.Universidade Federal da Bahia, Salvador (BA), Brazil.

*Corresponding author: alisson_ios@hotmail.com

\section{BACKGROUND}

Systemic lupus erythematosus (SLE) is a heterogeneous multiorgan disease of autoimmune etiology. Hepatic involvement occurs in $25-60 \%$ of patients with SLE at some point during the course of the disease. We present a SLE patient who developed severe liver dysfunction secondary to disease flare and/or cytomegalovirus (CMV) infection.

\section{CASE REPORT}

A 17-year-old female was admitted to our ward in December 2020. Two months prior to her admission she presented fever, weight loss, alopecia, and arthralgia. During her hospitalization she presented seizures. On physical examination, there was only palpable regional lymphadenopathy on her neck and axilla. The rest of the physical examination was unremarkable. Laboratory tests revealed leucopenia (white blood cell count: $2.19 \times 109 / \mathrm{L})$; lymphopenia $(0.44 \times 109 / \mathrm{L})$; thrombocytopenia $(144 \times 109 / \mathrm{L})$; anemia (hemoglobin, $8.3 \mathrm{~g} / \mathrm{dL})$; urinalysis with proteinuria $1+; 24 \mathrm{~h}$ proteinuria $0.842 \mathrm{~g}$; albumin $2.5 \mathrm{~g} / \mathrm{dL}$; serum creatinine $0.4 \mathrm{mg} / \mathrm{dL}$. Antinuclear antibody was positive 1:640 cytoplasmic dense fine speckled pattern, and complement fractions ( $\mathrm{C} 3$ and $\mathrm{C} 4$ ) were consumed but other autoantibodies were negative. Hepatic enzymes were elevated: AST (1011 U/L), ALT (261U/L), alkaline phosphatase (436 U/L), and GGT (372 U/L). Bilirubin and prothrombin time were normal. With the preliminary diagnosis of SLE, it was started prednisone $(1 \mathrm{mg} / \mathrm{kg} / \mathrm{day})$. Despite the treatment, two weeks later, she evolved with increased of serum AST (1436 U/L), ALT (263U/L), alkaline phosphatase (1025U/L), and GGT (1193U/L), as well as elevated total (10.0 mg/dL), and direct bilirubin (6.7 mg/dL). At this time, CMV IgM was detected in her serum. Cytomegalovirus PCR revealed 248 copies $/ \mathrm{mL}$ (reference: undetectable). Hemophagocytosis was not identified on bone marrow smear. Pulse therapy with $500 \mathrm{mg}$ methylprednisolone for 3 days was performed, associated with ganciclovir treatment $5 \mathrm{mg} / \mathrm{kg} /$ dose twice daily for 21 days. Interestingly, a liver biopsy revealed pure cholestatic syndrome, without lymphoid infiltrates or cytoplasmic and nuclear inclusions (Figure1). The patient evolved with gradual decrease of the hepatic enzymes and improvement of her constitutional symptoms and cytopenia. It was added mycophenolate mofetil ( $2 \mathrm{~g} /$ day) and hydroxychloroquine $(5 \mathrm{mg} / \mathrm{kg} / \mathrm{day}$ ) and prednisone was reduced.

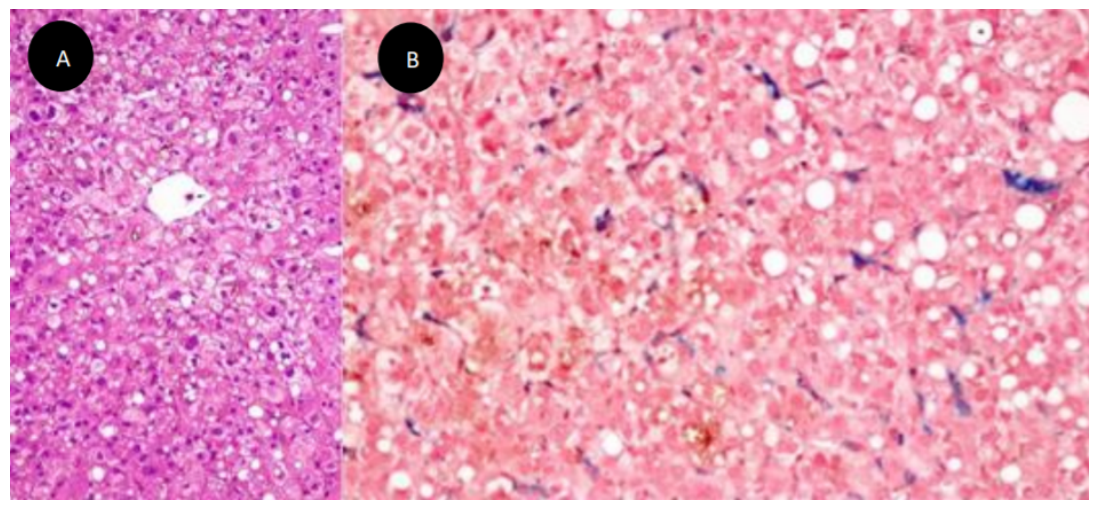

Figure 1.

\section{CONCLUSION}

Liver abnormalities in patients with SLE are generally due to the disease per se, drug-induced liver injury, fatty liver disease, association with other autoimmune liver diseases or viral hepatitis. In the present case, SLE itself and/or CMV infection could be responsible for the liver abnormalities.

\section{KEYWORDS}

Systemic lupus erythematosus, Cytomegalovirus infections, Liver failure.

Realização: 
